\title{
Patterns and Drivers of Atmospheric River Precipitation and Hydrologic Impacts across the Western United States $\mathscr{O}$
}

\author{
Christine M. Albano \\ Desert Research Institute, Reno, Nevada \\ Michael D. DetTinger \\ Water Mission Area, U.S. Geological Survey, Carson City, and Global Water Center, \\ University of Nevada, Reno, Reno, Nevada \\ ADRIAN A. HARPOLD \\ Department of Natural Resources and Environmental Science, and Global Water Center, \\ University of Nevada, Reno, Reno, Nevada
}

(Manuscript received 29 May 2019, in final form 25 November 2019)

\begin{abstract}
Atmospheric rivers (ARs) significantly influence precipitation and hydrologic variability in many areas of the world, including the western United States. As ARs are increasingly recognized by the research community and the public, there is a need to more precisely quantify and communicate their hydrologic impacts, which can vary from hazardous to beneficial depending on location and on the atmospheric and land surface conditions prior to and during the AR. This study leverages 33 years of atmospheric and hydrologic data for the western United States to 1) identify how water vapor amount, wind direction and speed, temperature, and antecedent soil moisture conditions influence precipitation and hydrologic responses (runoff, recharge, and snowpack) using quantile regression and 2) identify differences in hydrologic response types and magnitudes across the study region. Results indicate that water vapor amount serves as a primary control on precipitation amounts. Holding water vapor constant, precipitation amounts vary with wind direction, depending on location, and are consistently greater at colder temperatures. Runoff efficiencies further covary with temperature and antecedent soil moisture, with precipitation falling as snow and greater available water storage in the soil column mitigating flood impacts of large AR events. This study identifies the coastal and maritime mountain ranges as areas with the greatest potential for hazardous flooding and snowfall impacts. This spatially explicit information can lead to better understanding of the conditions under which ARs of different precipitation amounts are likely to be hazardous at a given location.
\end{abstract}

\section{Introduction}

On the U.S. West Coast, and in many coastal regions in the world, atmospheric rivers (ARs; American Meteorological Society 2018) have strong associations with extreme precipitation, flooding, and wind hazards (Waliser and Guan 2017). They also make beneficial

\footnotetext{
Supplemental information related to this paper is available at the Journals Online website: https://doi.org/10.1175/JHM-D-190119.s1.

Corresponding author: Christine M. Albano, christine.albano@ dri.edu
}

contributions to precipitation, mountain snowpacks, runoff, and reservoir storage that supply freshwater to millions of people (Dettinger et al. 2011; Guan et al. 2013). As a consequence of their importance, many recent research initiatives have been aimed at better forecasting (Cordeira et al. 2017) and characterizing their meteorological (e.g., Wick et al. 2013; Neiman et al. 2014) and hydrologic (e.g., Dettinger et al. 2011; Neiman et al. 2011; Ralph et al. 2013) impacts.

Vertically integrated water vapor transport (IVT) is a defining characteristic of ARs (American Meteorological Society 2018), with precipitation (Neiman et al. 2009, 2008; Rutz et al. 2014) and hydrologic impacts (Ralph et al. 2013; Konrad and Dettinger 2017) generally scaling 
proportionately with storm IVT amounts. Although water vapor transport in the atmosphere is a primary control on precipitation amount (Ralph et al. 2014), the strength of the relationships between AR IVT amount and precipitation varies substantially over the geography of the western United States. Daily AR IVT averages explain approximately $20 \%-56 \%(r=0.45-0.75)$ of the variability of precipitation for locations in mountainous areas, with the higher values corresponding to coastal mountains, Cascades, and the Sierra Nevada, while inland areas lacking terrain features generally have much lower correlations (Rutz et al. 2014). Some of this unexplained variability can be attributed to temporal variability in other factors related to vertical uplift and condensation that ultimately determine the efficiency with which water vapor is converted to precipitation; for example, the orientation of winds relative to terrain, the vertical distributions of wind, water vapor, and temperature that determine the ease with which uplift occurs, and the composition of clouds which determines how readily water vapor condenses to form precipitation (Dettinger et al. 2019).

The spatial and temporal variabilities of hydrologic responses (e.g., runoff, snowpack, recharge) for a given IVT amount are larger than is the case for precipitation, as variation in precipitation phase, land surface and subsurface characteristics, topography, and antecedent soil moisture conditions further modulate the hydrologic responses. The temperature of AR storms strongly relates to rain and snow accumulations (Guan et al. 2010) at high elevations and the incidence of rain-onsnow events (Guan et al. 2016) that can result in severe flooding. The hydrologic impacts for a given storm are further determined by geology, drainage density, water storage infrastructure, and land use (Lavers et al. 2012; Dettinger et al. 2019). Similarly, antecedent soil conditions can strongly influence runoff amounts (Ralph et al. 2013; Demaria et al. 2017; Leung and Qian 2009) as can snowpack amount (McCabe et al. 2007) and energy content (Würzer et al. 2016) during rain-on-snow events, which determines the degree to which additional runoff is produced from melted snowpack.

Site-specific studies have assessed the importance of AR characteristics (e.g., Ralph et al. 2003; Neiman et al. 2011; Hughes et al. 2014; Hecht and Cordeira 2017) and antecedent conditions (e.g., Ralph et al. 2013; Demaria et al. 2017) on precipitation and other hydrologic responses, but to date, this has not been done at a regional scale. In addition, several of these studies analyze only a limited number of storms. A regionally consistent analysis of the hydrologic impacts of ARs over an extended time period will help identify the broader drivers of AR impacts. This type of analysis also provides geographic and temporal context to site-specific or single-event studies so that researchers, managers, and the public can better distinguish where and when ARs are likely to be hazardous.

Our study leverages 33 years of atmospheric and hydrologic data to quantify the spatial and temporal variability of AR precipitation and hydrological impacts across the western United States (Fig. 1a). We further identify a subset of factors that explain this variability. In doing so, we address the following questions:

1) How do the magnitude and type of AR precipitation and associated hydrologic responses (contributions to soil moisture, snowpack, and runoff) vary with water vapor amount, wind direction and speed, temperature, and antecedent soil moisture conditions?

2) How do these hydrologic responses to ARs of different precipitation amounts vary over the western United States and what land surface characteristics explain these differences?

\section{Methods}

\section{a. Atmospheric river data}

We used a catalog of AR occurrences derived from the Modern-Era Retrospective analysis for Research and Applications, version 2 [MERRA-2; 3-hourly, instantaneous, assimilated meteorological fields V5.12.4 (M2I3NPASM); Gelaro et al. 2017] based on the Rutz et al. (2014) detection algorithm. This algorithm identifies ARs as contiguous areas with IVT $>250 \mathrm{~kg} \mathrm{~m}^{-1} \mathrm{~s}^{-1}$ that are greater than $2000 \mathrm{~km}$ in length. The catalog identifies the occurrence and instantaneous IVT value of ARs at 3-h time intervals for each $0.5^{\circ} \times 0.625^{\circ}(\sim 50 \mathrm{~km} \times 50 \mathrm{~km})$ grid cell across the study region.

For each grid cell, we selected AR events occurring during the winter months (October-April) from 1980 to 2013 for our analysis. AR events consisted of one or more consecutive days with at least one AR occurrence based on the 3-h data. Events were considered separate when no AR conditions occurred for at least one calendar day. For each event within a grid cell, the 3-h IVTs $\left(\mathrm{kg} \mathrm{m}^{-1} \mathrm{~s}^{-1}\right)$ were summed for the duration of the event to calculate storm total IVTs $\left(\mathrm{kg} \mathrm{m}^{-1}\right)$. Those events with storm total IVTs $<1.08 \times 10^{7} \mathrm{~kg} \mathrm{~m}^{-1}$ (e.g., $12 \mathrm{~h}$ at IVT $=250 \mathrm{~kg} \mathrm{~m}^{-1} \mathrm{~s}^{-1}$ or $6 \mathrm{~h}$ at $500 \mathrm{~kg} \mathrm{~m}^{-1} \mathrm{~s}^{-1}$ ) were filtered out to eliminate low intensity and short duration AR events. Because AR events were evaluated independently for each grid cell, the number and duration of events varies among grid cells.

For the analysis of temporal variability (see section 2c), IVT was broken up into its component parts of integrated 

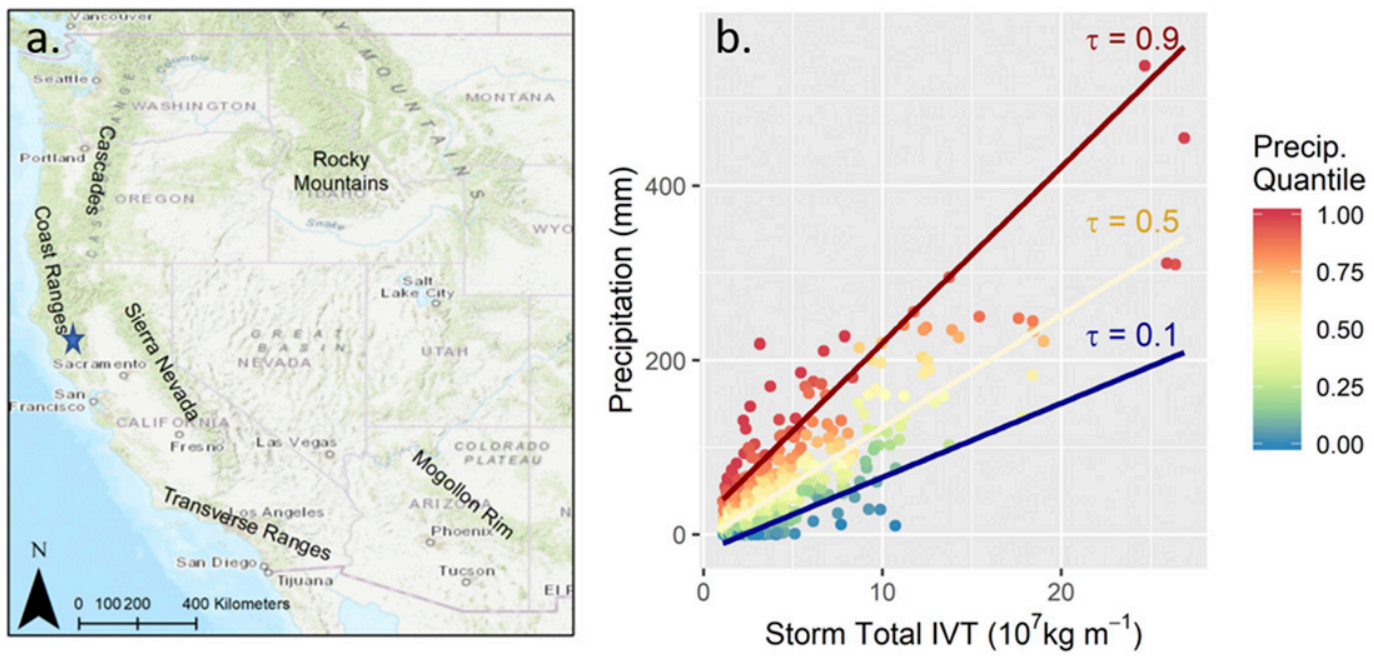

FIG. 1. (a) Western U.S. study area and (b) relationship between winter atmospheric river storm total integrated water vapor transport (IVT) and precipitation in the Mendocino Mountains [indicated by blue star in (a)] from 1980 to 2013. Increasing variance (heteroscedasticity) across the range of IVT values results in differing relationships (i.e., slopes) between predictor and responses conditioned on different quantiles $(\tau=0.1,0.5$, and 0.9$)$. Points are colored according to precipitation quantiles for eight bins of storm total IVT with equal sample sizes to help visualize model fit.

water vapor (IWV; $\mathrm{kg} \mathrm{m}^{-2}$ ) and humidity-weighted profile-average zonal $U$ and meridional $V$ winds $\left(\mathrm{m} \mathrm{s}^{-1}\right)$ so that the influences of each of these components could be assessed individually. IWV, $U, V$, and air temperature near the land surface $T\left({ }^{\circ} \mathrm{C}\right)$ were derived from the same MERRA-2 dataset and pressure levels as the Rutz et al. (2014) AR catalog using the following equations, then averaged for each day:

$$
\begin{aligned}
\mathrm{IWV} & =\frac{1}{g} \int_{p(\mathrm{ls})}^{200} q_{p} d p \\
U & =\frac{1}{g}\left(\frac{\int_{p(\mathrm{ls})}^{200} q_{p} \mathbf{u}_{p} d p}{\int_{p(\mathrm{ls})}^{200} q_{p} d p}\right), \\
V & =\frac{1}{g}\left(\frac{\int_{p(\mathrm{ls})}^{200} q_{p} \mathbf{v}_{p} d p}{\int_{p(\mathrm{ls})}^{200} q_{p} d p}\right), \text { and } \\
T & =T_{p(\mathrm{ls})},
\end{aligned}
$$

where $q=$ specific humidity $\left(\mathrm{kg} \mathrm{kg}^{-1}\right), \mathbf{u}=$ zonal wind vector $\left(\mathrm{m} \mathrm{s}^{-1}\right), \mathbf{v}=$ meridional wind vector $\left(\mathrm{m} \mathrm{s}^{-1}\right), g$ is the gravitational constant $\left(9.8 \mathrm{~m} \mathrm{~s}^{-2}\right)$, and $T=$ air temperature $\left({ }^{\circ} \mathrm{C}\right)$. Variable $p$ is equal to each of 23 pressure levels in the atmosphere and $d p$ is equal to the difference between each level at 25-hPa intervals between 1000 and
$700 \mathrm{hPa}$ and $50-\mathrm{hPa}$ intervals between 650 and $200 \mathrm{hPa}$. Parameter $p(\mathrm{ls})$ is the pressure level at the land surface (i.e., the bottommost pressure level containing temperature values). Daily $U, V$, and $T$ were averaged, and IWV was summed over all days of each AR event.

\section{b. Precipitation and hydrology data}

We used the daily, $1 / 16^{\circ}$ resolution dataset of meteorological variables and land surface states and fluxes (Livneh et al. 2015; available from ftp://192.12.137.7/ pub/dcp/archive/OBS/livneh2014.1_16deg/) derived from the Variable Infiltration Capacity (VIC; version 4.12) model (Liang et al. 1994) to estimate precipitation and associated hydrologic impacts (in $\mathrm{mm}$ ) for each event. This continent-wide dataset, as well as its predecessors (Livneh et al. 2013; Maurer et al. 2002), have been used to explore many questions in hydrology in the western United States (Livneh et al. 2013). Gridded datasets may underestimate precipitation amounts during individual storm events (Hughes et al. 2020) and can be particularly uncertain in complex terrain (Henn et al. 2018) and under synoptic conditions that are atypical relative to the long-term climatologies from which gridded datasets are derived (Lundquist et al. 2015). In addition, choices related to lapse rates and data screening can result in wide variation among datasets and we acknowledge that these sources of uncertainty, as well as the choice of land surface model, may affect our results. In terms of runoff simulation, the VIC model 
has been calibrated to simulate monthly flows in large river basins (Livneh et al. 2013) but has also been shown to simulate high flow frequencies (Wenger et al. 2010) and magnitudes (Safeeq et al. 2014) reasonably well in smaller watersheds of the Pacific Northwest and has been used successfully in studies of the Upper Colorado basin (Tang and Piechota 2009) and Sierra Nevada (Hidalgo et al. 2009). Gridded snow water equivalent (SWE) matches observations well in the Pacific Northwest (Safeeq et al. 2014) and other parts of the West (e.g., Mote et al. 2005). The fixed temperature lapse rate used in Livneh et al. (2015) has been shown to be cold-biased in complex terrain in coastal regions of California (Walton and Hall 2018), however, which could result in overestimation of SWE in these and potentially other places. Although soil moistures have not been widely validated in the western United States and are likely the most uncertain of the outputs used in our study, VIC simulates the long-term balance of runoff and ET reasonably well in montane regions (Barnhart et al. 2016). As compared to other land surface models that are part of the North American Land Data Assimilation (NLDAS-2), the VIC model shows superior performance in simulating streamflow, runoff, and SWE (Xia et al. 2018), but may overestimate baseflow (recharge) in arid regions and underestimate it in wetter regions (Niraula et al. 2017).

From the VIC model outputs, we extracted daily data that was either used or produced by the model, including precipitation (a gridded input to the VIC model), surface runoff, baseflow, soil moisture, and SWE to calculate five variables for analysis. These included one hydrologic forcing (event-total precipitation $P$ ) and three hydrologic response variables: surface runoff plus change in baseflow $(\Delta Q)$, change in snow water equivalent $(\triangle \mathrm{SWE})$, change in soil moisture $(\triangle \mathrm{SM})$, and one predictor variable: antecedent soil moisture (ANTSM). Precipitation $P$ was calculated as the sum of daily precipitation totals over the course of the event. The $\Delta$ SM and $\triangle \mathrm{SWE}$ were calculated as the difference between the beginning and end values of each $\mathrm{AR}$ event. Baseflow $\Delta Q$ was calculated as the sum of daily values of surface runoff and the sum of daily differences in baseflow during each AR event. ANTSM was calculated as the sum of water in soil layers 1-3 (total sum depth of the three soil layers ranges between 0.8 and $3 \mathrm{~m}$ ) on the day prior to each AR event.

\section{c. Analysis of influences of atmospheric and antecedent soil moisture conditions on precipitation and hydrologic responses to ARs}

The temporal variations of precipitation and hydrological responses to IVT results in response distributions with high degrees of heteroscedasticity (i.e., nonconstant variance; Fig. 1b) that do not meet assumptions of traditional statistical techniques such as ordinary least squares regression. Moreover, given that there can be a wide range of potential impacts for a given IVT (Fig. 1b), inferences based on traditional correlation or regression analysis, which characterize the mean response, may not be particularly useful. Quantile regression (Koenker and Bassett 1978) is a statistical method that offers a way to understand relationships for specified ranges (i.e., quantiles) of the response distribution and can offer novel insights into how a given predictor relates to the upper or lower limits of a response (i.e., limiting factors). This ability to quantify the upper and lower limits of responses can be quite useful for situational awareness as it enables prediction of the most likely best- and worst-case scenarios for a given value of the predictor variable.

For each $1 / 16$ th $^{\circ}$ grid cell in the Livneh dataset, we used quantile regression to model precipitation and the three hydrologic responses $(\triangle \mathrm{SM}, \Delta Q, \Delta \mathrm{SWE})$ to the individual components of IVT (IWV, $U, V$ ), and $T$. ANTSM also was included as a predictor variable in models for runoff and soil moisture responses, but not for precipitation and snowpack responses, as we did not hypothesize this variable to be influential in the latter cases. To model these relations, we used the "quantreg" package in R (Koenker 2018). We focused analyses on characterizing the $0.1,0.5$, and 0.9 th quantiles $(\tau=0.1$, $0.5,0.9)$ of the response distributions. In quantile regression, a statistical relationship is quantified between the entire range of the predictor variable and the subset of response values representing the particular quantile of interest. For example, a $\tau=0.1$ th quantile regression of IVT and precipitation quantifies the relationship between IVT and the smallest (near-lower limit) precipitation responses for a given IVT value, a $\tau=0.5$ th regression quantifies the median (i.e., central tendency) response, and a $\tau=0.9$ th regression quantifies the relationship between IVT and the largest (near-upper limit) precipitation responses for a given IVT value (Fig. 1b).

Only grid cells with 20 or more AR events over the course of the 1980-2013 time period were included to ensure a reasonable sample size. All predictor variables were standardized to a mean of 0 and standard deviation of 1 prior to analysis. Multicollinearity among predictor variables was assessed based on variance inflation factors for each predictor and grid cell and were generally less than 5 , suggesting that they were not problematic (Hair et al. 2010). We estimated 95\% confidence limits and associated $p$ values for the slope coefficients of each predictor and response based on the $x-y$ pair 
bootstrapping method (Koenker 1994). To assess model goodness of fits, we used differences in Akaike's information criterion ( $\triangle \mathrm{AIC}$ ) between fitted and null models for each quantile. Larger $\Delta \mathrm{AIC}$ values indicate a greater strength of evidence for the model, given the data, with values greater than 10 typically indicating reasonable support for the model (Burnham and Anderson 2002).

\section{d. Analysis of spatial variability of hydrologic responses to $A R s$}

To summarize subregional patterns of the hydrologic responses ( $\Delta \mathrm{SM}, \Delta Q, \Delta \mathrm{SWE})$ we conducted a $k$-means cluster analysis based on the 10th, 50th, and 90th percentiles of their overall distributions. We used these percentiles, rather than the mean, to better capture the range of changes in SWE responses. The $k$-means clustering therefore included nine variables (three hydrologic variables each with three percentiles). It was based on the MacQueen algorithm (MacQueen 1967) with 100 random starts and was performed in $\mathrm{R}$. We identified the six-cluster solution as optimal based on the point of inflection (i.e., elbow) of a plot of the number of clusters versus within-cluster sum of squares (i.e., scree plot). We calculated the spatial mean and standard deviation for each response percentile within each cluster and gave a descriptive name to each of six subregions (clusters) according to its characteristic responses to ARs. We then compared these subregions in terms of three sets of landscape features or conditions relating to 1) potential for orographic precipitation enhancement (elevation, slope, aspect, distance to coast), 2) runoff potential (VIC model parameters including soil column water storage capacity, variable infiltration capacity parameter, and saturated hydrologic conductivity), and 3) antecedent conditions (available storage left in the soil column given antecedent soil moisture) relative to event precipitation to identify potential causes of the differences in hydrologic responses among the six subregions.

\section{Results}

\section{a. Influences of atmospheric and antecedent soil moisture conditions on precipitation and hydrologic responses to $A R s$}

The number of recorded AR events varies considerably across the region, ranging from several hundred along the coastline to fewer than 50 events at many locations in the interior west (Fig. 2a). Average durations ranged between one and four days (Fig. 2b). Model goodness of fits, characterized as differences in AIC ( $\triangle \mathrm{AIC}$ ) between the fitted model and a null model based on the same quantile $\tau$, tend to be greater for the $\tau=0.9$ responses than for the $\tau=0.1$ or 0.5 responses but do not vary considerably among precipitation, soil moisture, and runoff responses (Fig. 3). Model goodness of fits are consistently lowest for the $\tau=0.1$ results, with the exception of SWE responses, which have higher $\triangle \mathrm{AICs}$ in lowland regions in the northern part of the study area. The $\Delta$ AICs vary spatially and are highest along the coast and at high elevations inland, indicating the best model fits in these areas (Fig. 3).

In the context of multiple linear quantile regression analysis with standardized predictor variables, each slope coefficient is interpreted as the direction and magnitude of change in the response variable for a one standard deviation change in the predictor, holding all other predictors constant and conditioned on the quantile being analyzed. Because spatial patterns of the $\tau=0.1$ and 0.5 results are generally similar to those of $\tau=0.9$ but model fits are relatively poorer for the lower quantiles due to a large number of events that had no precipitation response (see discussion in section $4 \mathrm{a}$ ), we focus mostly on results for the $\tau=0.9$ quantile (Fig. 4). Maps showing slope coefficients for $\tau=0.1$ and 0.5 results are included in the online supplemental material (Figs. S1 and S2).

As expected from the previous AR literature, storm total IWV is the strongest predictor of precipitation and other hydrologic impacts. Slope coefficients for IWV are consistently positive and significantly different from zero across most of the region. Slope coefficients are greatest in coastal and mountainous regions, with a one standard deviation change in storm total IWV resulting in precipitation increases of up to $200 \mathrm{~mm}$ in some of the highest impact locations (Fig. 4). Other hydrologic responses follow similar spatial patterns, but tend to be smaller, and in some cases are not significantly different from zero, due to the partitioning of precipitation into smaller amounts of SWE, runoff, soil moisture, and losses from evapotranspiration. Across much of the West, most AR precipitation is allocated to soil moisture (Fig. 4).

Storm orientation impacts, as indicated by zonal and meridional winds in the ARs, are evident in some locations. Holding all other predictors constant, increases in zonal winds, indicating more westerly (as opposed to more south or southwesterly) storm orientations result in relatively greater precipitation in the northernmost regions of the study area, including the windward side of the Cascades and Coastal ranges, and farther inland in the northern Rocky Mountains (" $U$ wind"; Fig. 4). Lower elevation areas on the lee sides of these ranges generally had less precipitation due to stronger rain shadow effects. In the southern portion 

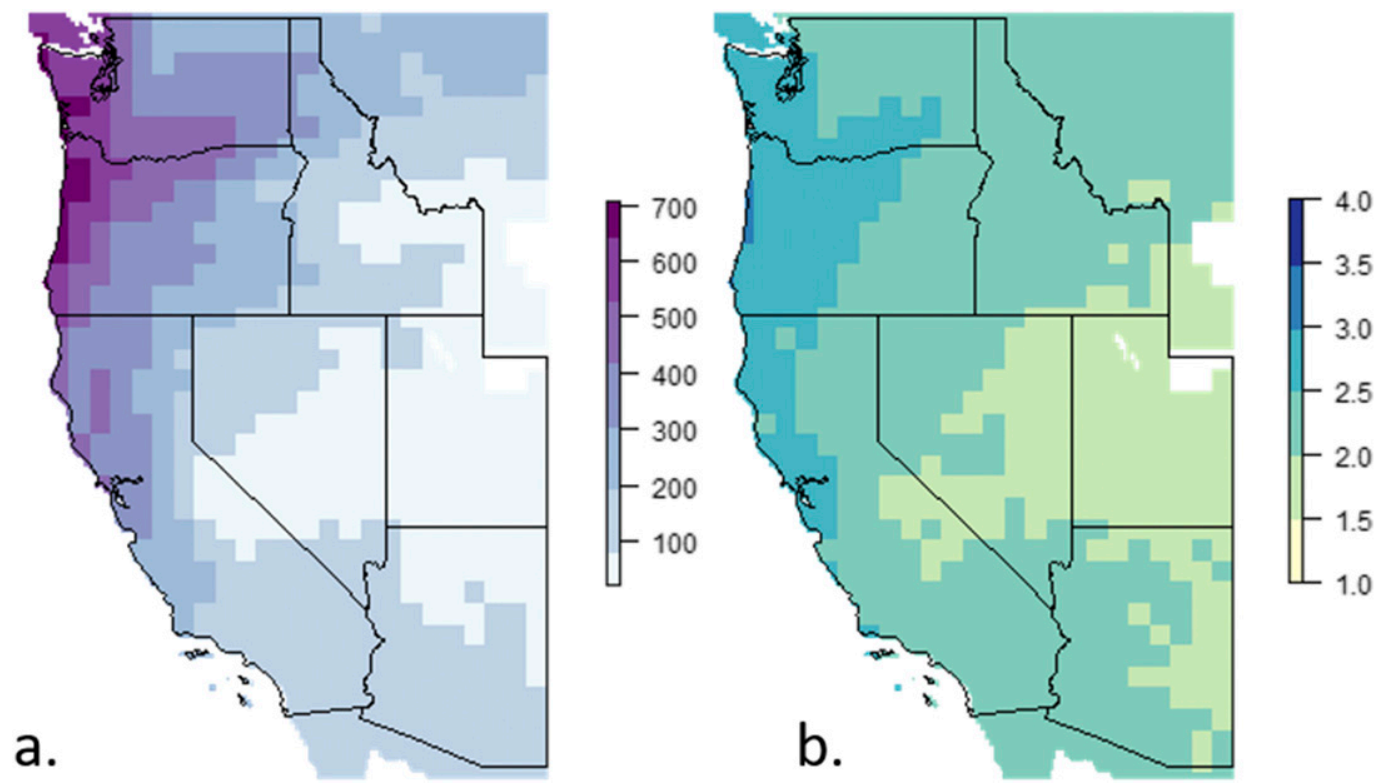

FIG. 2. (a) Number and (b) average duration (days) of atmospheric river (AR) events, October-April 1980-2015, based on the MERRA-2 reanalysis and the Rutz et al. (2014) AR catalog.

of the study region, positive effects of increased zonal winds on precipitation are especially strong along the highest elevation crests of the central and southern Sierra Nevada, but effects elsewhere are generally negative. These negative effects are observed in the Transverse Ranges of Southern California and across the Southwest, where local topography is better able to capture south to southwesterly storm orientations (Neiman et al. 2013; Hughes et al. 2014; Oakley et al. 2017). Increases in meridional winds (" $V$ wind"; Fig. 4 ) enhance precipitation across much of the region, with the largest impacts occurring in the mountains of California and along the southern aspects of the northern Rocky Mountains. In areas with the largest impacts, a one standard deviation increase in wind velocity results in an increase of up to $60 \mathrm{~mm}$ in precipitation (Fig. 4).

Surface air temperature impacts are also widespread, with precipitation consistently responding negatively to increases in temperature, holding all other predictors constant. A one standard deviation increase in temperature reduces precipitation amount by approximately $40 \mathrm{~mm}$ at the highest impact locations (Fig. 4). While negative responses to temperature are universal across the study area for precipitation and snowpack, slightly positive soil moisture and runoff responses are indicated at high elevations and northern latitudes because warmer storms in these colder locales have less than normal precipitation going into snowpack and more going toward soil moisture and runoff (Fig. 4).
The influence of antecedent soil moisture conditions on changes in soil moisture is not statistically significant across much of the region. However, responses are negative in some coastal regions of California and the Pacific Northwest (Fig. 4) and across the rest of the region, relations are slightly positive. Positive influences of antecedent soil moisture on runoff are widespread, and are most evident in a few areas within coastal ranges of California, the Sierra Nevada, and the Transverse Ranges of California.

\section{b. Spatial variability of hydrologic responses to ARs}

The six hydrologic response subregions identified through the cluster analysis vary in terms of both magnitude and types of hydrologic responses (Fig. 5). Subregions were named according to their characteristic hydrologic responses to AR precipitation. The flood-producing subregion (mostly located in the mid to high elevations of the coastal ranges, Sierra Nevada and Cascades) is notable for its large runoff response (Fig. 5), including 90th percentile runoff responses and negative 10th percentile SWE responses (Fig. S3). The runoff-producing subregion (moderate to low elevation parts of the same ranges) is also characterized by increased runoff responses to ARs and negative SWE, but of smaller magnitudes (Fig. 5, Fig. S3). The high (at the highest elevations of the Sierra Nevada and Cascades) and low (on rain-shadow sides of the Sierra Nevada and Cascades and in the Idaho and western Montana Rockies) snow-producing subregions are notable for their positive 
$P$
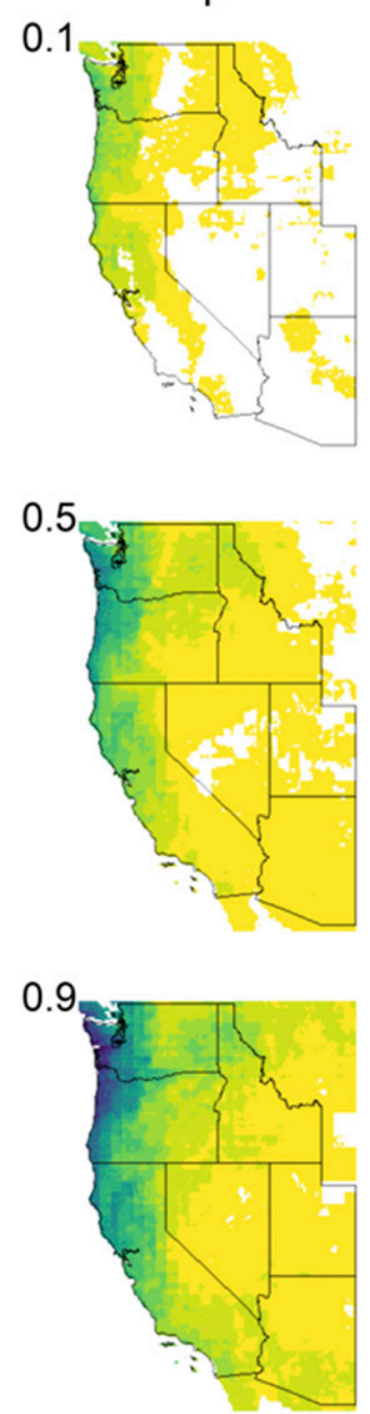

$\Delta S M$
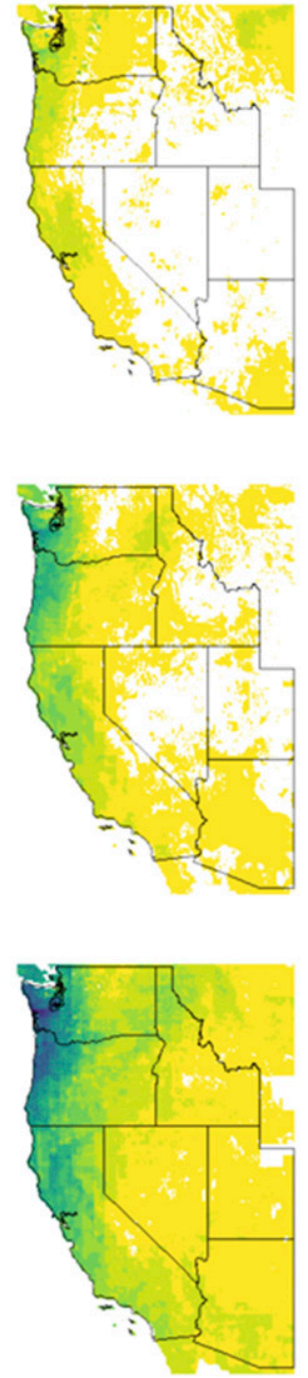

$\Delta \mathrm{Q}$
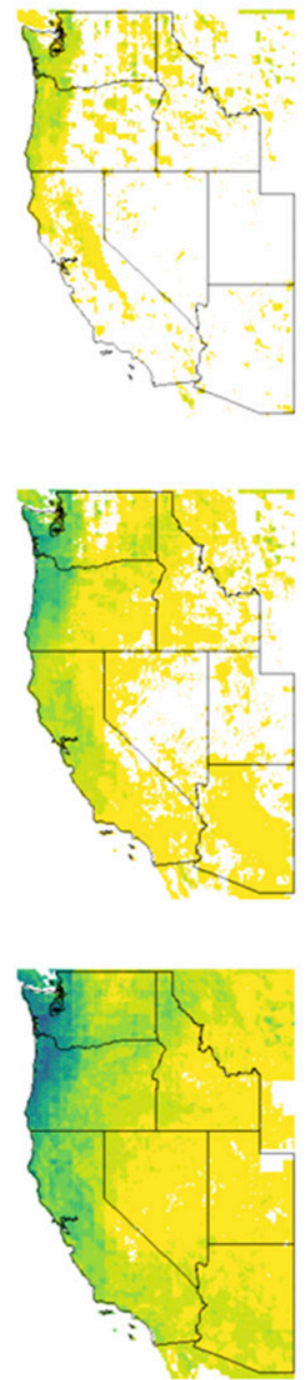

$\triangle S W E$

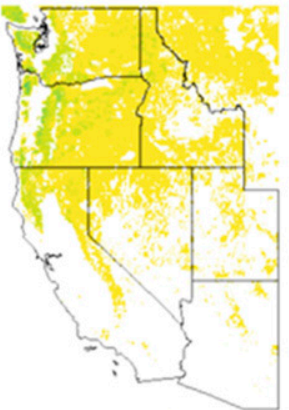

$\triangle \mathrm{AIC}$
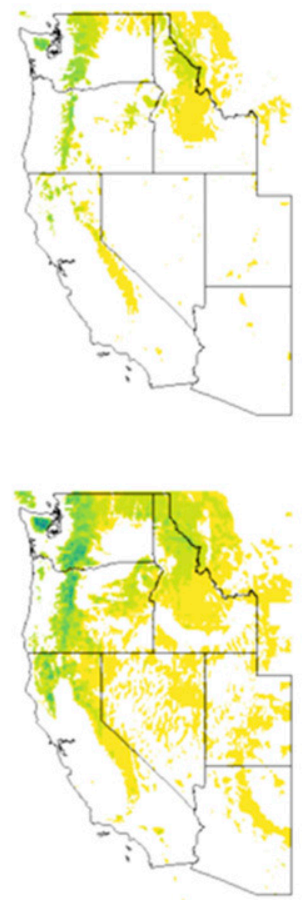

FIG. 3. Goodness of fits for $\tau=0.1,0.5$, and 0.9 quantile regression models that predict precipitation $(P)$, change in soil moisture $(\Delta \mathrm{SM})$, runoff $(Q)$, and change in snowpack $(\Delta \mathrm{SWE})$. Goodness-of-fit estimates are based on the differences in Akaike's information criterion $(\triangle \mathrm{AIC})$ values between the fitted model and a null model. Only $\Delta \mathrm{AIC}$ values $>10$, indicating reasonable model fits, are shown.

SWE responses of high and low magnitudes, respectively. Hydrologic responses to ARs in the high and low rechargeproducing subregions (across California's Central Valley and much of the interior West) mostly are additions to soil moisture, with the former exhibiting a greater response than the latter. Although subregional differences are largely driven by precipitation amounts, they also differ in hydrologic partitioning of precipitation regardless of the amount, with partitioning reflecting each subregion's characteristic response (Fig. 6).

Variability of VIC model parameters representing orographic enhancement and runoff potential within each of these six subregions is wide for most physical characteristics analyzed (Fig. 7) but there are substantial differences between subregions in average values for the variable infiltration parameter, total water storage capacity of the soil column, aspect, distance to coast, and elevation in particular. Differences in mean slope between subregions are relatively minor. Both precipitation amounts and antecedent available water storage space in the soil column differ among subregions (Fig. 8). Subregions also differ in terms of the relative amounts of precipitation they receive and the available amounts of storage that their soils provide. For example, event precipitation is nearly equal to storage in the flood-producing subregion while large disparities exist 

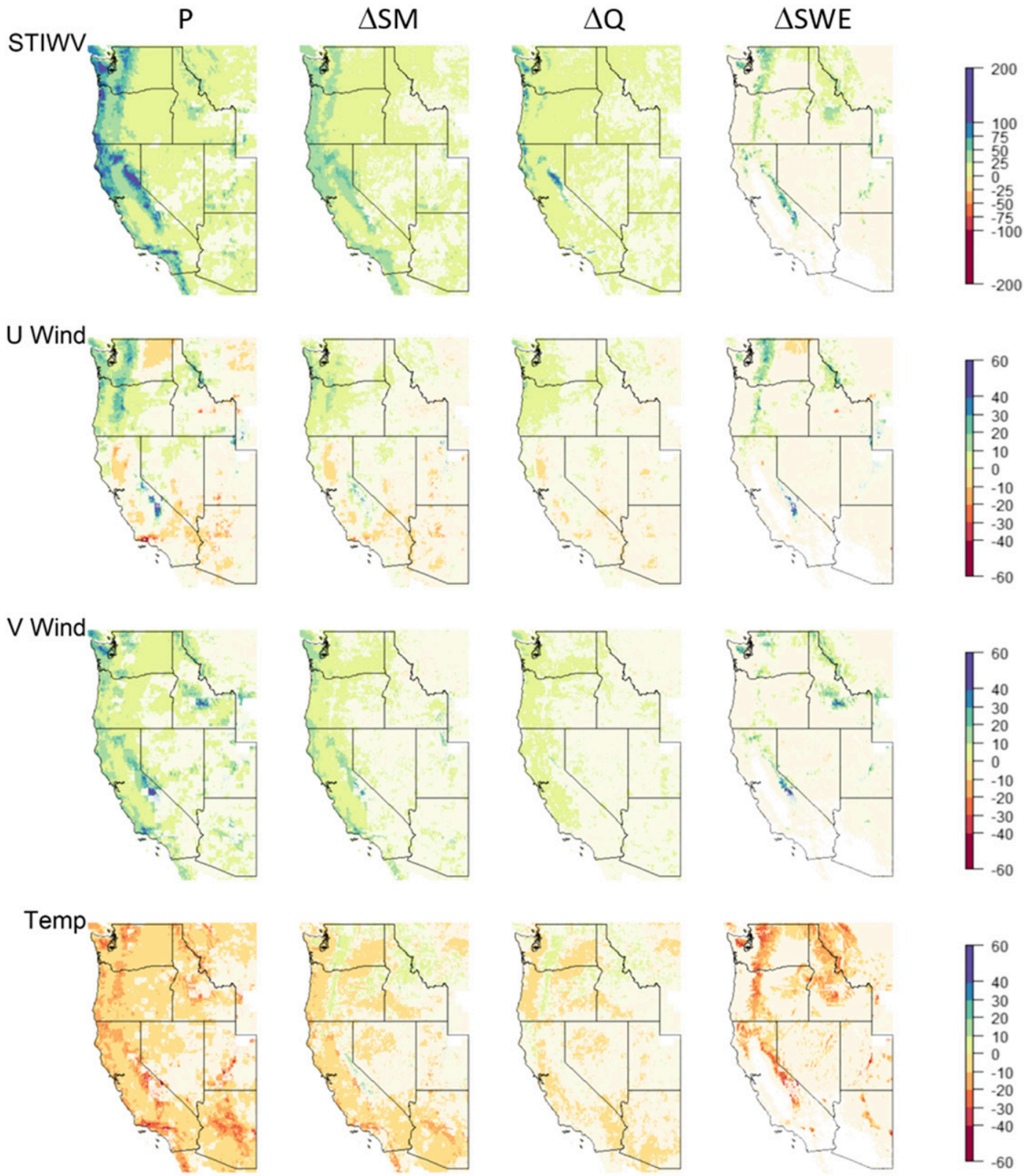

Ant. SM
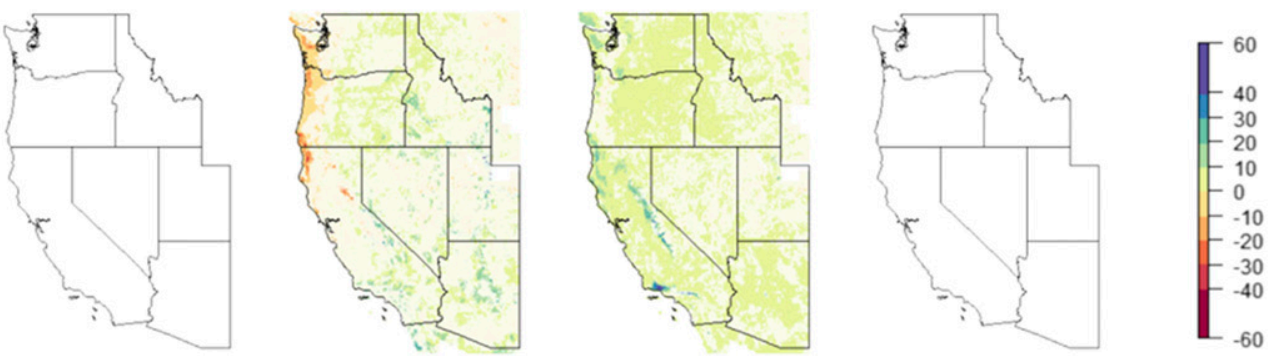

FIG. 4. Slope coefficients of each predictor-response relation from quantile regression analysis conditioned on the $\tau=0.9$ quantile. Muted colors indicate slope is not significantly different from zero at a $95 \%$ confidence level. Predictor variables include storm total integrated water vapor (STIWV), zonal ( $U$ wind) and meridional ( $V$ wind) wind components, surface air temperature (Temp), and antecedent soil moisture (Ant. SM). Response variables include precipitation $(P)$, change in soil moisture $(\Delta \mathrm{SM})$, runoff $(Q)$, and change in snowpack $(\Delta \mathrm{SWE})$. 


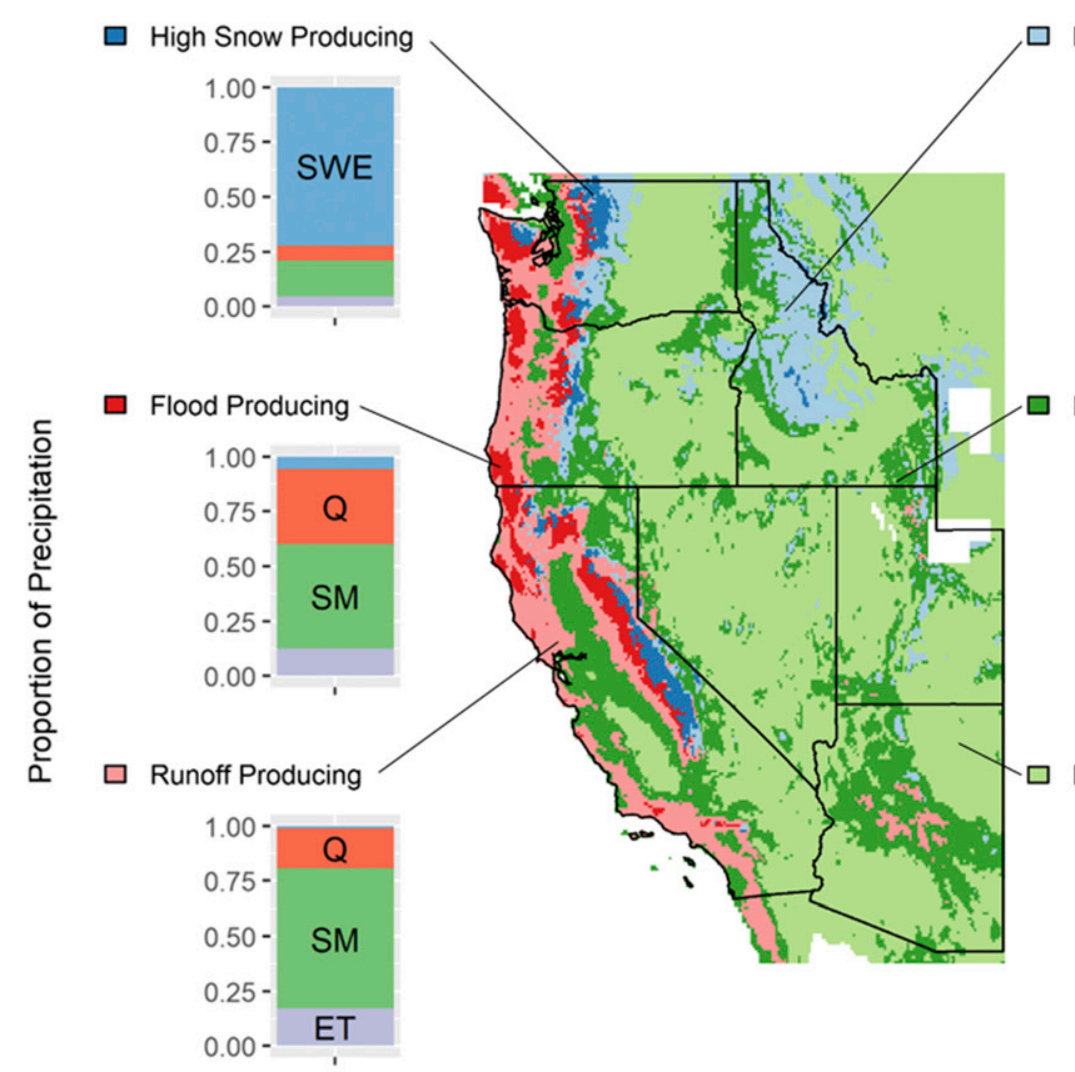

Low Snow Producing

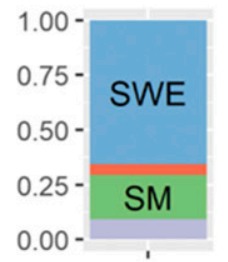

High Recharge Producing

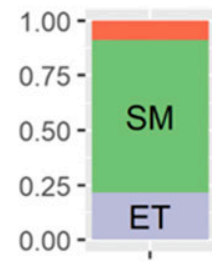

Low Recharge Producing
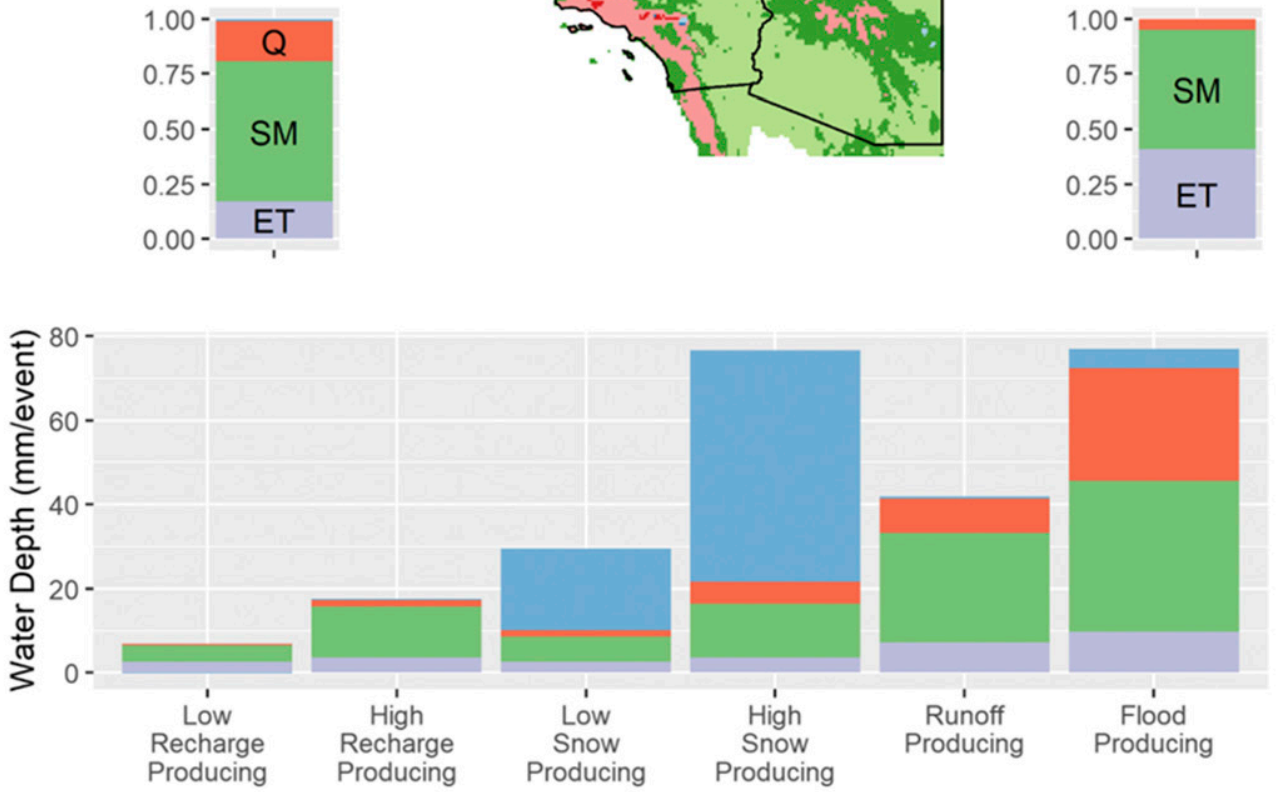

Snowpack (SWE)

Runoff (Q)

Soil Recharge (SM)

Evapotranspiration (ET)

FIG. 5. Atmospheric river hydrologic response subregions identified through $k$-means clustering of the 10th, 50th, and 90th percentiles of three hydrologic response types (changes in soil moisture, runoff, and snow water equivalent). Bar charts indicate the subregional average hydrologic response across all AR events both proportionally (upper charts) and in absolute terms (lower bar chart).

between precipitation amount and available storage in the low recharge-producing subregion at the other end of the spectrum (Fig. 8). The high snow-producing region has larger available soil moisture storage amounts relative to the runoff and flood-producing regions despite having similar precipitation due to most of the precipitation being stored in the snowpack. For the flood- and runoff-producing regions, in particular, 90th percentile precipitation events coincide with smaller amounts of antecedent available storage and 10th percentile precipitation events tend to coincide with larger amounts. 

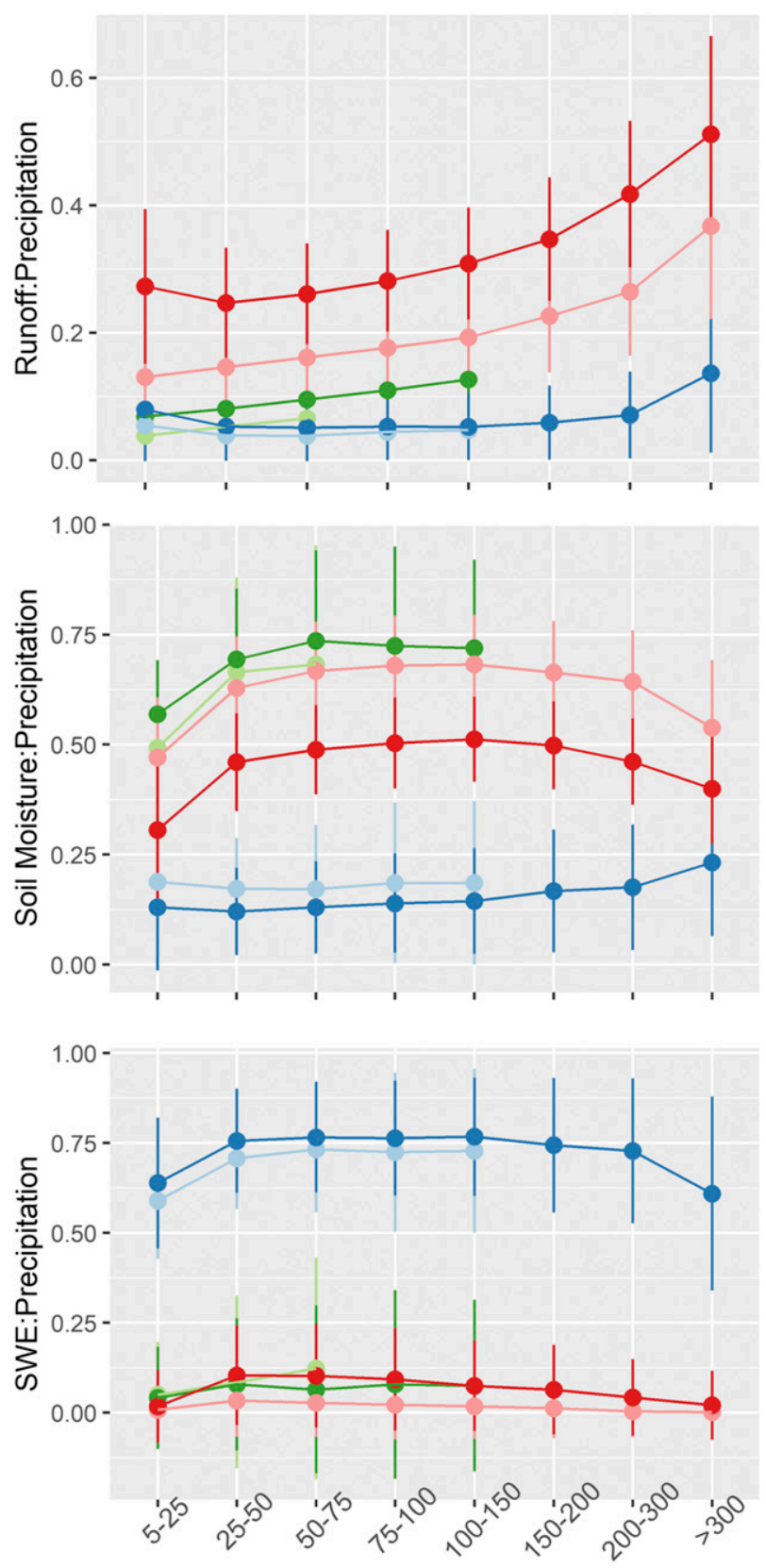

Precipitation Category ( $\mathrm{mm})$

\section{Low Recharge Producing High Recharge Producing \\ Low Snow Producing \\ High Snow Producing \\ Runoff Producing \\ Flood Producing}

FIG. 6. Averages and standard deviations of runoff, recharge, and SWE ratios by hydrologic response subregion (see Fig. 5) across categories of storm total precipitation amounts. Values for a given precipitation category are only shown if the precipitation amount occurred in greater than $50 \%$ of the pixels in the region.

\section{Discussion}

\section{a. Influences of atmospheric and antecedent soil moisture conditions on precipitation and hydrologic responses to ARs}

The quantile regression approach provides unique insights relative to more traditional regression approaches focused on the average or central tendency of the response for two reasons. First, quantile regression determines the degree to which water vapor and other predictors used in this analysis exert control over the (near) upper limits of precipitation and hydrologic responses when other factors are not limiting. These strong observed 0.9th quantile relations have the potential to be particularly useful for situational awareness and hazard response readiness because they provide statistically significant estimates of the upper end of the range of potential impacts for a given set of forcing conditions. Second, quantile regression indicates how unmeasured or unanalyzed limiting factors (Cade and Noon 2003) can, in some cases, be influential enough so as to almost completely negate the influences of the predictors used in this analysis (i.e., as reflected in the $\tau=0.1$ results where a large number of events had no precipitation response), suggesting a need to better understand the importance of other factors that influence precipitation, beyond just IVT. For example, other timevarying factors that relate to precipitation generation such as atmospheric stability and the abundance of aerosols and other cloud condensation nuclei, which were not included as predictors in our analysis, are important determinants of precipitation amounts (Ralph et al. 2016) and may explain why some events lacked precipitation responses. Their exclusion was, in part, due to the need to limit the number of predictor variables in our analysis given our limited sample size (i.e., number of events), especially in the interior West (Fig. 2), and also because these factors tend to be less well measured and captured at the coarse resolution of the MERRA-2 data we used.

The importance of wind direction and storm orientation to precipitation and other hydrologic impacts are well documented for several locations in the western United States, including the Mogollon Rim of Arizona (Rivera et al. 2014; Hughes et al. 2014; Neiman et al. 2013), locations in northern and central coastal California (Ralph et al. 2003; Hecht and Cordeira 2017), the transverse ranges of southern California (Oakley et al. 2017), and in western Washington (Neiman et al. 2011). As might be expected, our results indicate that most mountain ranges exhibit sensitivities to storm (wind) orientation. The positive influence of zonal winds was particularly strong at the highest elevations of the Sierra 

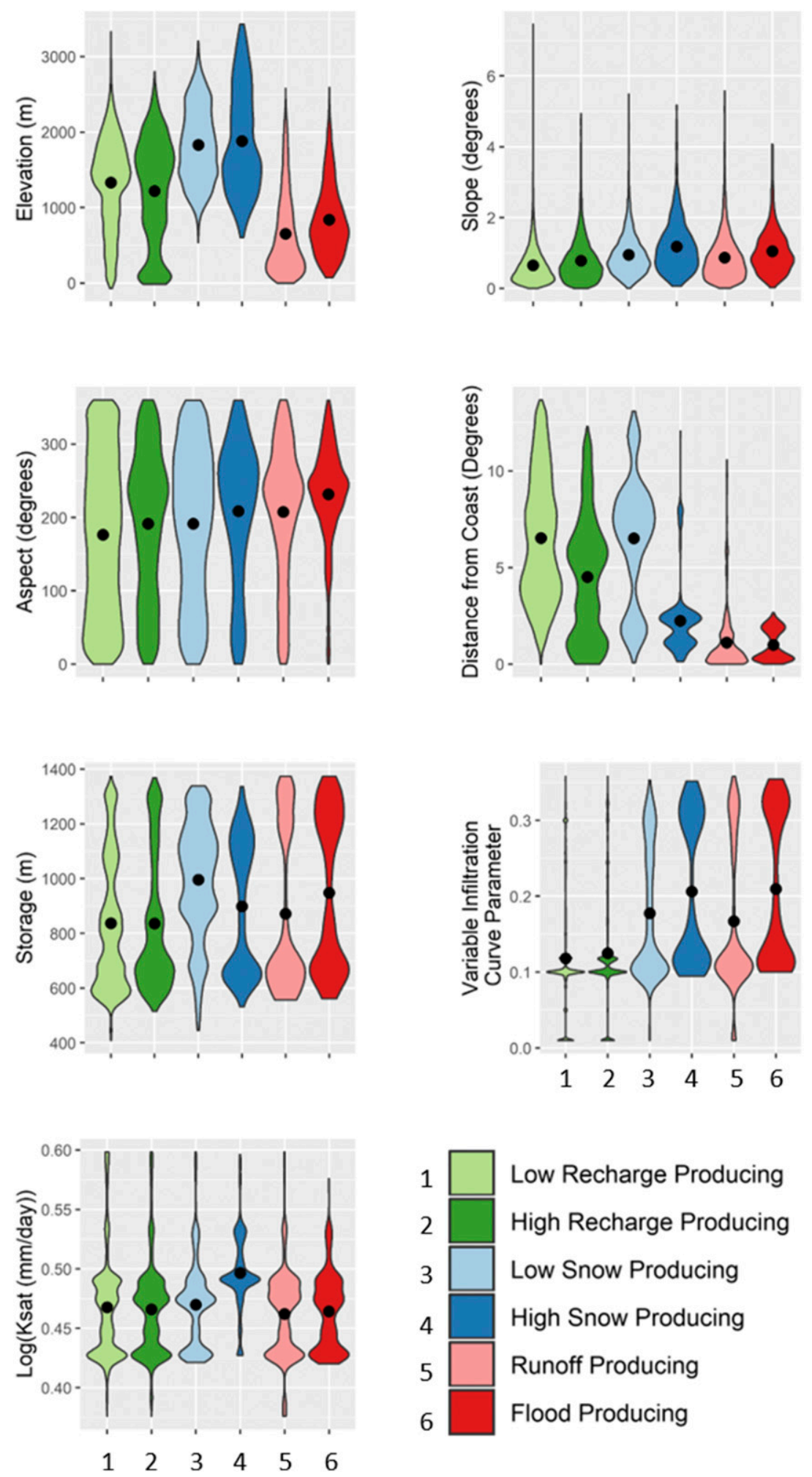

FIG. 7. Spatial averages (black dots) and distributions of selected landscape features or conditions for each hydrologic response subregion (see Fig. 5). 


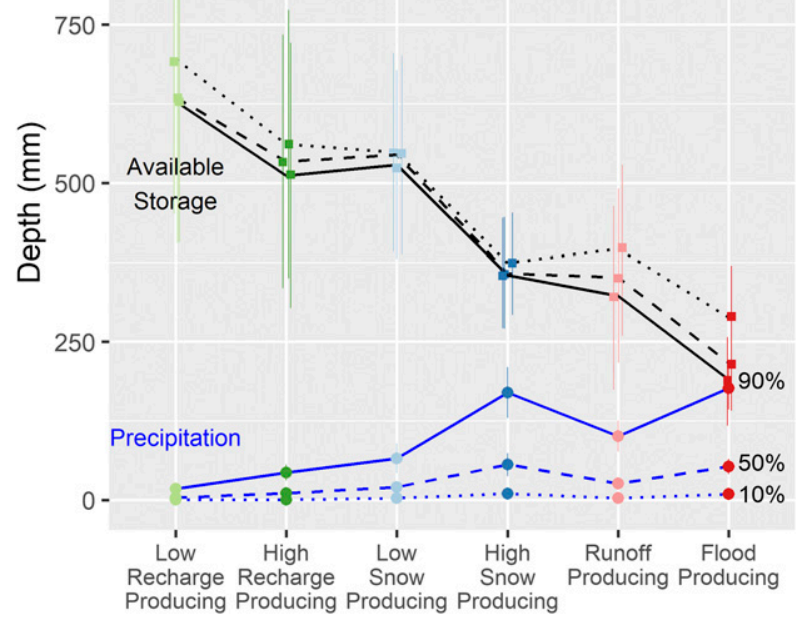

FIG. 8. Spatial averages and standard deviations for 10th, 50th, and 90th percentile (dotted, dashed, and solid line types) precipitation (blue) amounts and corresponding available water storage (black) within the soil column (i.e., average amount of available storage one day prior to events within $\pm 5 \%$ of each precipitation percentile) for each hydrologic response subregion (see Fig. 5).

Nevada, where greater zonal wind strength has been associated with stronger orographic precipitation gradients (Lundquist et al. 2010) and in the Pacific Northwest, where inland penetrating ARs follow a predominantly eastward path from the coast to the northern Rockies (Alexander et al. 2015; Swales et al. 2016; Rutz et al. 2015). In contrast, increased zonal winds suppressed precipitation across much of the southern extent of the study region by causing more westerly storm orientations that result in less orographic uplift due to the orientation of the terrain (Neiman et al. 2013; Hughes et al. 2014; Oakley et al. 2017).

Across the entire study region, precipitation is consistently enhanced with increasing meridional winds; places where this was especially evident included the Northern and Central Sierra Nevada, coastal ranges throughout California, Oregon, and Washington, and the southern front of the Sawtooth Range in Idaho. Positive influences of meridional transport are to be expected on more southerly-oriented slopes and as more southwesterly-oriented AR landfalls below about $32^{\circ} \mathrm{N}$ are able to enter the interior west through terrain gaps to the south of the Sierra Nevada. Nevertheless, the near-ubiquitous positive influence of meridional transport (Fig. 4) is interesting. Our results correspond well with $\mathrm{Hu}$ et al. (2017), who demonstrate that lowerlatitude, more southwesterly-oriented ARs, associated with cyclonic Rossby wave breaking tend to have longer lifespans, more vertical fluxes of heat, wind, and water vapor, and greater terrain interaction (and thus have more widespread precipitation influences) than those making landfall farther to the north. More northerly ARs in their study are associated with anticyclonic Rossby wave breaking, more easterly winds, and strong orographic enhancement along the Cascades and Sierra Nevada, similar to what we observed.

Multiple influences of AR temperatures are observed, including effects on total precipitation amounts, and on the partitioning of precipitation into soil moisture, runoff, and snow water equivalent. Holding all other predictors constant, greater precipitation amounts are observed with colder temperatures across most of the study area, and in some cases, with comparable effect sizes to those for winds. Although it is possible that this relationship is correlational rather than causational, temperature may influence precipitation efficiency (defined as precipitation/total available IVT) in accordance with one or both of the mechanisms described in Kirshbaum and Smith (2008): 1) condensation rates increase with decreasing temperature, following the Clausius-Clapeyron relationship, so that precipitation efficiency (of available IVT) also increases and 2) cold cloud processes cause more supersaturated water vapor to be converted to precipitation through ice-phase vapor deposition and riming. Satellite-based observations suggest this latter process may be occurring as colder cloud temperatures have been associated with greater precipitation amounts (Matrosov 2013). Although we ultimately used surface air temperature for this analysis, we note here that results did not differ when we instead used temperature metrics aloft in the atmosphere (e.g., 700-hPa temperature or humidity-weighted profile-average temperature). Another possible explanation is that precipitation efficiency is driven by nontemperature dynamical or thermodynamical aspects of ARs that vary seasonally and that are thus correlated with seasonal variation of temperatures. Site specific analysis of precipitation responses indicates stronger relations with temperature than with seasonality (Fig. S4).

The magnitude and widespread significance of the observed temperature effects on precipitation amounts in our analysis suggest that 1) storm temperature (or seasonality) provides information that can be useful for predicting precipitation efficiency for a given water vapor transport, and 2) although water vapor transport and storm precipitation amount and intensity are expected to substantially increase in a warmer climate (Westra et al. 2014; Kunkel et al. 2013), precipitation efficiencies may have a more complex response. For example, substantial temperature effects on precipitation efficiency 
have been demonstrated based on numerical modeling across numerous mountain ranges of the U.S. Intermountain West under current and projected future climatic conditions (Eidhammer et al. 2018).

The responses of soil moisture, runoff, and snow water equivalent to temperature integrate the effects of temperature on precipitation efficiency, the partitioning of precipitation into rain versus snow, and atmospheric water demands. Temperature had the expected strong negative relationship with changes in snow water equivalent in most high-elevation mountain ranges, reflecting both greater snow-rain ratios and increased precipitation efficiencies under colder temperatures. Temperature effects on runoff and soil moisture were generally negative across most of the region, likely reflecting reduced precipitation efficiencies as well as greater atmospheric water demand in all but the highest elevations in higher-latitude mountain ranges. In these latter locations, temperature had a positive effect on soil moisture recharge and runoff due to precipitation occurring as rain, rather than snow.

Positive impacts of antecedent soil conditions on runoff tend to be stronger and more widespread in the California mountains relative to coastal and Cascade ranges in Oregon and Washington. In these coastal and Cascade regions, antecedent soil moisture has negative impacts on AR-induced changes in soil moisture and little influence on runoff variability, likely reflecting soils that are consistently close to saturation throughout the winter. In the more arid regions of California winter soil moisture has greater variability (Sheffield et al. 2004) and in turn is more influential on runoff response. These results are generally consistent with the observation that the largest streamflow responses to winter storms in the coastal Pacific Northwest closely correspond with storm precipitation amounts (Berghuijs et al. 2016). In contrast, the largest streamflow responses in nonsnowmelt-dominated areas farther inland and to the south correspond with precipitation excesses-the differences between precipitation amount and available storage in the soil column (Berghuijs et al. 2016).

\section{b. Spatial variability of hydrologic responses to ARs}

The six subregions identified in this study represent different characteristic hydrologic responses, distinguishing areas where immediate flood risks are more likely to be prevalent under high intensity or long duration $A R$ conditions from those where the primary contribution of ARs is to terrestrial water inputs to soil moisture or snowpack storage. These distinctions are valuable as ARs are becoming increasingly recognized by the public for their role in extreme precipitation and flooding (Ralph et al. 2019), requiring more precise communication of potential hazards (or lack thereof) based on both the forecasted strength of the storm and the attributes of the area over which it is occurring. The results of this study suggest that both of these factors are necessary, given the significant variation of impacts observed over both time (Fig. 4) and space (Fig. 5).

The primary axes on which the six hydrologic response subregions vary are clearly related to storm precipitation amounts and phases, but they also differ considerably with respect to antecedent soil moisture conditions coincident with storm timing (Fig. 8). The natural separation of clusters we derived based on AR responses was similar to other clusterings based on precipitation timing, phase, and aridity of the seasonal water balance (Berghuijs et al. 2014), indicating the role ARs play in determining this balance.

Differences in average physical conditions among hydrologic response subregions tend to be subtle given large within subregion variations for many variables but can explain some differences in responses. For example, the small variable infiltration capacity curve parameter (resulting in more infiltration and less runoff) distinguishes the high- and low-recharge subregions from the others, with slope, aspect, and coastal distance contributing to slightly higher precipitation in the former subregion, despite the latter having higher average elevation. The lack of significant runoff responses in these subregions is due to small precipitation amounts and ample available storage in the soil column (Fig. 8), resulting in only rare occurrences of saturation excess runoff, the primary runoff generating mechanism modeled by VIC. These subregions represent important but much less-well-recognized responses to ARs that tend to be subtle at the event scale, but can have significant cumulative effects over the course of a season as soil moisture resource enhancement by winter ARs support increased vegetation productivity in water-limited ecosystems (Albano et al. 2017) and, ultimately, groundwater recharge.

Greater average precipitation and less available storage in the soil column characterize the flood-producing subregions relative to others (Fig. 8) and may be explained by factors that enhance orographic precipitation (i.e., higher elevations, steeper slopes, more westerly aspects). The flood- and runoff-producing subregions also differ from each other in terms of runoff ratios (Fig. 6), which are driven, in part, by calibrated model parameters that emphasize saturation excess surface runoff, including total potential storage in the soil column and the variable infiltration curve parameter (Liang et al. 1994). Although the flood-producing subregion has greater potential soil moisture storage than most subregions (Fig. 7), available storage (Fig. 8) is 
consistently less, indicating that strong seasonal synchronies between antecedent soil moisture and precipitation enhances flood magnitudes and frequencies (Sivapalan et al. 2005). Strong synchronies between greater antecedent soil moisture amounts and larger AR storms are also indicated by less available storage during 90th percentile precipitation events relative to 10th or 50th percentile events (Fig. 8). A similar pattern was observed by Ralph et al. (2013), with longer duration ARs with larger precipitation totals in coastal California tending to occur in December-February seasons and preceded by higher antecedent soil moisture.

The two AR snow-producing subregions were higher in elevation than the others. Although these two regions had similar elevations (Fig. 7) and SWE:precipitation ratios (Fig. 6), the high snow-producing subregion had greater overall precipitation amounts (Fig. 8). This may be explained by differences in proximity to the coast, aspect (the high snow-producing subregion is primarily west facing), and slight differences in slope. Soil parameters pertaining to infiltration and storage capacity also differ between these two groups, with less available storage, a larger infiltration curve parameter (meaning less infiltration and more runoff), and higher saturated hydrologic conductivity (meaning more drainage) in the high snow-producing subregion. These relations suggest that lower-elevation areas in the high snow-producing subregion, where transitions from snow to rain are most likely to occur under warming climate, and where available storage is more limited, will likely behave more similarly to the flood-producing subregion in the future.

\section{Conclusions}

This study quantified the influences of atmospheric and land surface characteristics on AR storm-total precipitation and hydrologic impacts. Although we did not specifically disentangle the effects of storm intensity versus duration, these results are likely to be strongly driven by storm duration given that this is the primary determinant of precipitation totals in the western United States (Lamjiri et al. 2017). Future studies focused more explicitly on storm intensities may yield different results with respect to runoff amounts, particularly related to subdaily flood peaks.

This study demonstrates the greater sensitivity of the upper limits of precipitation and hydrologic responses to atmospheric and land surface conditions as compared to the lower limits or central tendencies. The latter are more often the focus of standard regression or composite analyses. These results, among others (e.g., Lausier and Jain 2018), suggest that this focus on the central tendency of a response to environmental drivers can lead to an underestimation of extreme precipitation risks. In this regard, quantile regression is demonstrated to provide a much richer characterization of AR-precipitationhydrology relationships. The focus here upon 10thand 90th-percentile responses serves to bracket likely ranges of hydrologic outcomes; information that is most salient to estimation of flood and other AR-related risks. Indeed, quantile-regression analyses might be useful complements to many standard (operational, ensemblebased) probabilistic forecasts. For example, forecasted AR properties (like IVT and temperatures) could be used to drive regression models for comparison to operational forecast bounds in ways that serve as reality check and can also focus attention on the strongest and weakest forecast elements for particular storms.

This study also quantifies the significant roles that wind orientation, temperature, and antecedent soil conditions play in modifying precipitation and runoff efficiencies. Water vapor conducted by ARs is generally expected to increase substantially in a warming climate, which will translate to more precipitation from AR storms (Payne and Magnusdottir 2015; Warner and Mass 2017; Warner et al. 2015; Hagos et al. 2016; Shields and Kiehl 2016; Dettinger 2011; Gao et al. 2015). However, the future of AR wind directions and speeds is much less certain (Gao et al. 2015; Payne and Magnusdottir 2015; Warner et al. 2015; Shields and Kiehl 2016). The substantial geographic variations in precipitation and hydrologic sensitivities to AR winds observed here indicate that responses to future dynamical changes in ARs will be complex. Warming temperatures will directly drive a variety of hydrologic responses to ARs explored here, including increased water input intensity (Harpold and Kohler 2017; Yan et al. 2018) and flood hazards with changes from snow to rain and potential impacts to precipitation efficiencies (Eidhammer et al. 2018). The present study offers a unique approach for predicting and monitoring hydrologic impacts of ARs as they change in the future.

Acknowledgments. This material is based upon work supported by the Science Applications for Risk Reduction (SAFRR) program in the U.S. Geological Survey's Natural Hazards Mission Area under Grants G16AC00304 and G18-00405 and by the National Aeronautics and Space Administration under Grant NNX15AIO2H. We wish to thank Jon Rutz for the use of his atmospheric rivers catalog and Ben Livneh for his support in the use of the Variable Infiltration Capacity model data. Eric Morway, Maureen McCarthy, Stephanie McAfee, and three anonymous reviewers provided comments that helped to improve this manuscript. 


\section{REFERENCES}

Albano, C. M., M. D. Dettinger, and C. E. Soulard, 2017: Influence of atmospheric rivers on vegetation productivity and fire patterns in the southwestern US. J. Geophys. Res. Biogeosci., 122, 308-323, https://doi.org/10.1002/2016JG003608.

Alexander, M. A., J. D. Scott, D. Swales, M. Hughes, K. Mahoney, and C. A. Smith, 2015: Moisture pathways into the U.S. Intermountain West associated with heavy winter precipitation events. J. Hydrometeor., 16, 1184-1206, https://doi.org/ 10.1175/JHM-D-14-0139.1.

American Meteorological Society, 2018: Atmospheric river. Glossary of Meteorology, http://glossary.ametsoc.org/wiki/ Atmospheric_river.

Barnhart, T. B., N. P. Molotch, B. Livneh, A. A. Harpold, J. F. Knowles, and D. Schneider, 2016: Snowmelt rate dictates streamflow. Geophys. Res. Lett., 43, 8006-8016, https://doi.org/ 10.1002/2016GL069690.

Berghuijs, W. R., M. Sivapalan, R. A. Woods, and H. Savenije, 2014: Patterns of similarity of seasonal water balances: A window into streamflow variability over a range of time scales. Water Resour. Res., 50, 5638-5661, https://doi.org/10.1002/ 2014WR015692.

__, R. A. Woods, C. J. Hutton, and M. Sivapalan, 2016: Dominant flood generating mechanisms across the United States. Geophys. Res. Lett., 43, 4382-4390, https://doi.org/ 10.1002/2016GL068070.

Burnham, K. P., and D. R. Anderson, 2002: Model Selection and Multimodel Inference: A Practical Information-Theoretic Approach. 2nd ed. Springer, $488 \mathrm{pp}$.

Cade, B. S., and B. R. Noon, 2003: A gentle introduction to quantile regression for ecologists. Front. Ecol. Environ., 1, 412-420, https://doi.org/10.1890/1540-9295(2003)001[0412:AGITQR] 2.0.CO;2.

Cordeira, J. M., F. M. Ralph, A. Martin, N. Gaggini, J. R. Spackman, P. J. Neiman, J. J. Rutz, and R. Pierce, 2017: Forecasting atmospheric rivers during CalWater 2015. Bull. Amer. Meteor. Soc., 98, 449-459, https://doi.org/10.1175/ BAMS-D-15-00245.1.

Demaria, E. M. C., F. Dominguez, H. Hu, G. von Glinski, M. Robles, J. Skindlov, and J. Walter, 2017: Observed hydrologic impacts of landfalling atmospheric rivers in the Salt and Verde River basins of Arizona, United States. Water Resour. Res., 53, 10 025-10 042, https://doi.org/10.1002/2017WR020778.

Dettinger, M. D., 2011: Climate change, atmospheric rivers, and floods in California-A multimodel analysis of storm frequency and magnitude changes. J. Amer. Water Resour. Assoc., 47, 514 523, https://doi.org/10.1111/j.1752-1688.2011.00546.x.

_ , F. M. Ralph, T. Das, P. J. Neiman, and D. R. Cayan, 2011: Atmospheric Rivers, Floods and the Water Resources of California. Water, 3, 445-478, https://doi.org/10.3390/w3020445.

—, D. Lavers, J. Rutz, M. Viale, A. Wade, and A. B. White, 2019: Effects of atmospheric rivers. Atmospheric Rivers, F. M. Ralph et al., Eds., Springer, 149-187.

Eidhammer, T., V. Grubišić, R. Rasmussen, and K. Ikdea, 2018: Winter precipitation efficiency of mountain ranges in the Colorado Rockies under climate change. J. Geophys. Res. Atmos., 123, 2573-2590, https://doi.org/10.1002/2017JD027995.

Gao, Y., J. Lu, L. R. Leung, Q. Yang, S. Hagos, and Y. Qian, 2015: Dynamical and thermodynamical modulations on future changes of landfalling atmospheric rivers over western North America. Geophys. Res. Lett., 42, 7179-7186, https://doi.org/ 10.1002/2015GL065435.
Gelaro, R., and Coauthors, 2017: The Modern-Era Retrospective Analysis for Research and Applications, Version 2 (MERRA-2). J. Climate, 30, 5419-5454, https://doi.org/10.1175/JCLI-D16-0758.1.

Guan, B., N. P. Molotch, D. E. Waliser, E. J. Fetzer, and P. J. Neiman, 2010: Extreme snowfall events linked to atmospheric rivers and surface air temperature via satellite measurements. Geophys. Res. Lett., 37, L20401, https://doi.org/10.1029/ 2010GL044696.

in California's Sierra Nevada: Role of atmospheric rivers and modes of large-scale variability. Water Resour. Res., 49, 6731-6743, https://doi.org/10.1002/wrcr.20537.

— D. E. Waliser, F. M. Ralph, E. J. Fetzer, and P. J. Neiman, 2016: Hydrometeorological characteristics of rain-on-snow events associated with atmospheric rivers. Geophys. Res. Lett., 43, 2964-2973, https://doi.org/10.1002/2016GL067978.

Hagos, S. M., L. R. Leung, J. Yoon, J. Lu, and Y. Gao, 2016: A projection of changes in landfalling atmospheric river frequency and extreme precipitation over western North America from the Large Ensemble CESM simulations. Geophys. Res. Lett., 43, 1357-1363, https://doi.org/10.1002/ 2015GL067392.

Hair, J. F. J., W. C. Black, B. J. Babin, and R. E. Anderson, 2010: Multivariate Data Analysis.7th ed. Pearson, 816 pp.

Harpold, A. A., and M. Kohler, 2017: Potential for changing extreme snowmelt and rainfall events in the mountains of the western United States. J. Geophys. Res. Atmos., 122, 13 219-13 228, https://doi.org/10.1002/2017JD027704.

Hecht, C. W., and J. M. Cordeira, 2017: Characterizing the influence of atmospheric river orientation and intensity on precipitation distributions over North Coastal California. Geophys. Res. Lett., 44, 9048-9058, https://doi.org/10.1002/ 2017GL074179.

Henn, B., A. J. Newman, B. Livneh, C. Daly, and J. D. Lundquist, 2018: An assessment of differences in gridded precipitation datasets in complex terrain. J. Hydrol., 556, 1205-1219, https:// doi.org/10.1016/j.jhydrol.2017.03.008.

Hidalgo, H. G., and Coauthors, 2009: Detection and attribution of streamflow timing changes to climate change in the western United States. J. Climate, 22, 3838-3855, https://doi.org/ 10.1175/2009JCLI2470.1.

Hu, H., F. Dominguez, Z. Wang, D. A. Lavers, G. Zhang, and F. M. Ralph, 2017: Linking atmospheric river hydrological impacts on the U.S. West Coast to Rossby wave breaking. J. Climate, 30, 3381-3399, https://doi.org/10.1175/JCLI-D-16-0386.1.

Hughes, M., K. M. Mahoney, P. J. Neiman, B. J. Moore, M. Alexander, and F. M. Ralph, 2014: The landfall and inland penetration of a flood-producing atmospheric river in Arizona. Part II: Sensitivity of modeled precipitation to terrain height and atmospheric river orientation. J. Hydrometeor., 15, 1954 1974, https://doi.org/10.1175/JHM-D-13-0176.1.

_ J. D. Lundquist, and B. Henn, 2020: Dynamical downscaling improves upon gridded precipitation products in the Sierra Nevada, California. Climate Dyn., https://doi.org/10.1007/ s00382-017-3631-z, in press.

Kirshbaum, D., and R. Smith, 2008: Temperature and moiststability effects on midlatitude orographic precipitation. Quart. J. Roy. Meteor. Soc., 134, 1183-1199, https://doi.org/ 10.1002/qj.274.

Koenker, R., 1994: Confidence intervals for regression quantiles. Asymptotic Statistics, P. Mandl and M. Huskova, Eds., SpringerVerlag, 349-359. 
_ 2018: quantreg: Quantile regression, version 5.36. R Package, https://cran.r-project.org/package = quantreg.

- , and G. Bassett, 1978: Regression quantiles. Econometrica, 46, 33-50, https://doi.org/10.2307/1913643.

Konrad, C. P., and M. D. Dettinger, 2017: Flood runoff in relation to water vapor transport by atmospheric rivers over the western United States, 1949-2015. Geophys. Res. Lett., 44, 11 456-11 462, https://doi.org/10.1002/2017GL075399.

Kunkel, K. E., T. R. Karl, D. R. Easterling, K. Redmond, J. Young, X. Yin, and P. Hennon, 2013: Probable maximum precipitation and climate change. Geophys. Res. Lett., 40, 1402-1408, https://doi.org/10.1002/grl.50334.

Lamjiri, M. A., M. D. Dettinger, F. M. Ralph, and B. Guan, 2017: Hourly storm characteristics along the U.S. West Coast: Role of atmospheric rivers in extreme precipitation. Geophys. Res. Lett., 44, 7020-7028, https://doi.org/10.1002/ 2017 GL074193.

Lausier, A. M., and S. Jain, 2018: Overlooked trends in observed global annual precipitation reveal underestimated risks. Nat. Sci. Reports, 8, 16 746, https://doi.org/10.1038/s41598-018-34993-5.

Lavers, D. A., G. Villarini, R. P. Allan, E. F. Wood, and A. J. Wade, 2012: The detection of atmospheric rivers in atmospheric reanalyses and their links to British winter floods and the large-scale climatic circulation. J. Geophys. Res., 117, D20106, https://doi.org/10.1029/2012JD018027.

Leung, R. L., and Y. Qian, 2009: Atmospheric rivers induced heavy precipitation and flooding in the western U.S. simulated by the WRF regional climate model. Geophys. Res. Lett., 36, L03820, https://doi.org/10.1029/2008GL036445.

Liang, X., D. P. Lettenmaier, E. F. Wood, and S. J. Burges, 1994: A simple hydrologically based model of land surface water and energy fluxes for general circulation models. J. Geophys. Res., 99, 14 415-14 428, https://doi.org/10.1029/94JD00483.

Livneh, B., E. A. Rosenberg, C. Lin, B. Nijssen, V. Mishra, K. M. Andreadis, E. P. Maurer, and D. P. Lettenmaier, 2013: A longterm hydrologically based dataset of land surface fluxes and states for the conterminous United States: Update and extensions. J. Climate, 26, 9384-9392, https://doi.org/10.1175/ JCLI-D-12-00508.1.

, T. J. T. Bohn, D. W. D. Pierce, F. Munoz-Arriola, B. Nijssen, R. Vose, D. Cayan, and L. D. Brekke, 2015: A spatially comprehensive, hydrometeorological data set for Mexico, the U.S., and Southern Canada 1950-2013. Sci. Data, 2, 150042, https://doi.org/10.1038/sdata.2015.42.

Lundquist, J. D., J. R. Minder, P. J. Neiman, and E. Sukovich, 2010: Relationships between barrier jet heights, orographic precipitation gradients, and streamflow in the northern Sierra Nevada. J. Hydrometeor., 11, 1141-1156, https://doi.org/ 10.1175/2010JHM1264.1.

— B. Henn, M. Hughes, B. Livneh, P. Neiman, E. D. Gutmann, and J. Dozier, 2015: High-elevation precipitation patterns: Using snow measurements to assess daily gridded datasets across the Sierra Nevada, California. J. Hydrometeor., 16, 1773-1792, https://doi.org/10.1175/JHM-D-15-0019.1.

MacQueen, J., 1967: Some methods for classification and analysis of multivariate observations. Proceedings of the Fifth Berkeley Symposium on Mathematical Statistics and Probability, L. M. Le Cam and J. Neyman, Eds., University of California Press, 281-297.

Matrosov, S. Y., 2013: Characteristics of landfalling atmospheric rivers inferred from satellite observations over the eastern North Pacific Ocean. Mon. Wea. Rev., 141, 3757-3768, https:// doi.org/10.1175/MWR-D-12-00324.1.
Maurer, E. P., A. Wood, J. Adam, D. P. Lettenmaier, and B. Nijssen, 2002: A long-term hydrologically based dataset of land surface fluxes and states for the conterminous United States. J. Climate, 15, 3237-3251, https://doi.org/10.1175/ 1520-0442(2002)015<3237:ALTHBD>2.0.CO;2.

McCabe, G. J., M. P. Clark, and L. E. Hay, 2007: Rain-on-snow events in the western United States. Bull. Amer. Meteor. Soc., 88, 319-328, https://doi.org/10.1175/BAMS-88-3-319.

Mote, P. W., A. F. Hamlet, M. P. Clark, and D. P. Lettenmaier, 2005: Declining mountain snowpack in western North America. Bull. Amer. Meteor. Soc., 86, 39-49, https://doi.org/10.1175/ BAMS-86-1-39.

Neiman, P. J., F. M. Ralph, G. Wick, J. D. Lundquist, and M. D. Dettinger, 2008: Meteorological characteristics and overland precipitation impacts of atmospheric rivers affecting the west coast of North America based on eight years of SSM/I satellite observations. J. Hydrometeor., 9, 22-47, https://doi.org/10.1175/ 2007JHM855.1.

_ A. B. White, F. M. Ralph, D. J. Gottas, and S. I. Gutman, 2009: A water vapour flux tool for precipitation forecasting. Proc. Inst. Civ. Eng. Manag., 162, 83-94, https://doi.org/ 10.1680/wama.2009.162.2.83.

—, L. J. Schick, F. M. Ralph, M. Hughes, and G. Wick, 2011: Flooding in western Washington: The connection to atmospheric rivers. J. Hydrometeor., 12, 1337-1358, https://doi.org/ 10.1175/2011JHM1358.1.

—, F. M. Ralph, B. J. Moore, M. Hughes, K. M. Mahoney, J. M. Cordeira, and M. D. Dettinger, 2013: The Landfall and inland penetration of a flood-producing atmospheric river in Arizona. Part I: Observed synoptic-scale, orographic, and hydrometeorological characteristics. J. Hydrometeor., 14, 460-484, https:// doi.org/10.1175/JHM-D-12-0101.1.

, and R. J. Zamora, 2014: The regional influence of an intense Sierra Barrier Jet and landfalling atmospheric river on orographic precipitation in Northern California: A case study. J. Hydrometeor., 15, 1419-1439, https://doi.org/10.1175/ JHM-D-13-0183.1.

Niraula, R., T. Meixner, H. Ajami, M. Rodell, D. Gochis, and C. L. Castro, 2017: Comparing potential recharge estimates from three land surface models across the western US. J. Hydrol., 545, 410-423, https://doi.org/10.1016/ j.jhydrol.2016.12.028.

Oakley, N. S., J. T. Lancaster, M. L. Kaplan, and F. M. Ralph, 2017: Synoptic conditions associated with cool season post-fire debris flows in the Transverse Ranges of southern California. Nat. Hazards, 88, 327-354, https://doi.org/10.1007/s11069-0172867-6.

Payne, A. E., and G. Magnusdottir, 2015: An evaluation of atmospheric rivers over the North Pacific in CMIP5 and their response to warming under RCP 8.5. J. Geophys. Res. Atmos., 120, 11 111-173, 190, https://doi.org/10.1002/2015JD023586.

Ralph, F. M., P. J. Neiman, D. E. Kingsmill, P. O. G. Persson, A. B. White, E. T. Strem, E. D. Andrews, and R. C. Antweiler, 2003: The impact of a prominent rain shadow on flooding in California's Santa Cruz Mountains: A CALJET case study and sensitivity to the ENSO cycle. J. Hydrometeor., 4, 12431264, https://doi.org/10.1175/1525-7541(2003)004<1243:TIOAPR > 2.0.CO;2.

—, T. Coleman, P. J. Neiman, R. J. Zamora, and M. D. Dettinger, 2013: Observed impacts of duration and seasonality of atmospheric-river landfalls on soil moisture and runoff in coastal Northern California. J. Hydrometeor., 14, 443-459, https://doi.org/10.1175/JHM-D-12-076.1. 
— , and Coauthors, 2014: A vision of future observations for western US extreme precipitation and flooding. J. Contemp. Water Resour. Res. Educ., 153, 16-32, https://doi.org/10.1111/ j.1936-704X.2014.03176.x.

_ quantify the roles of atmospheric rivers and aerosols in modulating U.S. West Coast precipitation in a changing climate. Bull. Amer. Meteor. Soc., 97, 1209-1228, https://doi.org/ 10.1175/BAMS-D-14-00043.1.

—, M. Dettinger, J. M. Cordeira, J. J. Rutz, L. Schick, M. Anderson, C. Smallcomb, and D. Reynolds, 2019: A scale to characterize the strength and impacts of atmospheric rivers. Bull. Amer. Meteor. Soc., 100, 269-879, https://doi.org/10.1175/ BAMS-D-18-0023.1.

Rivera, E. R., F. Dominguez, and C. L. Castro, 2014: Atmospheric rivers and cool season extreme precipitation events in the Verde River basin of Arizona. J. Hydrometeor., 15, 813-829, https://doi.org/10.1175/JHM-D-12-0189.1.

Rutz, J. J., W. J. Steenburgh, and F. M. Ralph, 2014: Climatological characteristics of atmospheric rivers and their inland penetration over the western United States. Mon. Wea. Rev., 142, 905-921, https://doi.org/10.1175/MWR-D-13-00168.1.

,-- , and -2015 : The inland penetration of atmospheric rivers over western North America: A Lagrangian analysis. Mon. Wea. Rev., 143, 1924-1944, https://doi.org/10.1175/ MWR-D-14-00288.1.

Safeeq, M., G. S. Mauger, G. E. Grant, I. Arismendi, A. F. Hamlet, and S.-Y. Lee, 2014: Comparing large-scale hydrological model predictions with observed streamflow in the Pacific Northwest: Effects of climate and groundwater. J. Hydrometeor., 15, 2501-2521, https://doi.org/10.1175/JHM-D-13-0198.1.

Sheffield, J., G. Goteti, F. Wen, and E. F. Wood, 2004: A simulated soil moisture based drought analysis for the United States. J. Geophys. Res., 109, D24108, https://doi.org/10.1029/ 2004JD005182.

Shields, C. A., and J. T. Kiehl, 2016: Atmospheric river landfall-latitude changes in future climate simulations. Geophys. Res. Lett., 43, 8775-8782, https://doi.org/10.1002/ 2016GL070470.

Sivapalan, M., G. Blöschl, R. Merz, and D. Gutknecht, 2005: Linking flood frequency to long-term water balance: Incorporating effects of seasonality. Water Resour. Res., 41,1-17, https://doi.org/ 10.1029/2004WR003439.

Swales, D., M. Alexander, and M. Hughes, 2016: Examining moisture pathways and extreme precipitation in the U.S
Intermountain West using self-organizing maps. Geophys. Res. Lett., 43, 1727-1735, https://doi.org/10.1002/2015GL067478.

Tang, C., and T. C. Piechota, 2009: Spatial and temporal soil moisture and drought variability in the Upper Colorado River Basin. J. Hydrol., 379, 122-135, https://doi.org/10.1016/ j.jhydrol.2009.09.052.

Waliser, D., and B. Guan, 2017: Extreme winds and precipitation during landfall of atmospheric rivers. Nat. Geosci., 10, 179-183, https://doi.org/10.1038/ngeo2894.

Walton, D., and A. Hall, 2018: An assessment of high-resolution gridded temperature datasets over California. J. Climate, $\mathbf{3 1}$, 3789-3810, https://doi.org/10.1175/JCLI-D-17-0410.1.

Warner, M., and C. F. Mass, 2017: Changes in the climatology, structure, and seasonality of northeast Pacific atmospheric rivers in CMIP5 climate simulations. J. Hydrometeor., 18, 2131-2141, https://doi.org/10.1175/JHM-D-16-0200.1.

, - — and E. P. Salathé, 2015: Changes in winter atmospheric rivers along the North American west coast in CMIP5 climate models. J. Hydrometeor., 16, 118-128, https://doi.org/10.1175/ JHM-D-14-0080.1.

Wenger, S. J., C. H. Luce, A. F. Hamlet, D. J. Isaak, and H. M. Neville, 2010: Macroscale hydrologic modeling of ecologically relevant flow metrics. Water Resour. Res., 46, W09513, https:// doi.org/10.1029/2009WR008839.

Westra, S., and Coauthors, 2014: Future changes to the intensity and frequency of short-duration extreme rainfall. Rev. Geophys., 52, 522-555, https://doi.org/10.1002/2014RG000464.

Wick, G. A., P. J. Neiman, F. M. Ralph, and T. M. Hamill, 2013: Evaluation of forecasts of the water vapor signature of atmospheric rivers in operational numerical weather prediction models. Wea. Forecasting, 28, 1337-1352, https://doi.org/ 10.1175/WAF-D-13-00025.1.

Würzer, S., T. Jonas, N. Wever, and M. Lehning, 2016: Influence of initial snowpack properties on runoff formation during rainon-snow events. J. Hydrometeor., 17, 1801-1815, https:// doi.org/10.1175/JHM-D-15-0181.1.

Xia, Y., and Coauthors, 2018: Comprehensive evaluation of the Variable Infiltration Capacity (VIC) model in the North American Land Data Assimilation System. J. Hydrometeor., 19, 1853-1879, https://doi.org/10.1175/JHM-D-18-0139.1.

Yan, H., N. Sun, M. Wigmosta, R. Skaggs, Z. Hou, and R. Leung, 2018: Next-generation intensity-duration-frequency curves for hydrologic design in snow-dominated environments. Water Resour. Res., 54, 1093-1108, https://doi.org/10.1002/ 2017WR021290. 